may well take its place in contributing towards the post-war design of museums and galleries, and to the choice of environment considered best for works of art. It is possible that full air-conditioning of such institutions in large cities and certain other places might be found to be financially desirable, when the sums spent annually in restoration and repair of paintings are critically reviewed. Careful inspection will always be needed, but the experience so far of housing a collection of pictures below ground under controlled conditions, scientifically planned, is decidedly encouraging. It would be a pity if some of this could not be translated into terms appropriate to times of peace. Many great pictures are probably now going through severe hardships and many vicissitudes. Those for which the Trustees of the National Gallery are responsible, however, are at present enjoying a climate of such salubrity that the greatest problem for the future is to foresee how they will react when they leave it.

\section{WILD BIRDS AND HOME-GROWN FOOD IN BRITAIN}

\section{By Dr. WALTER E. COLLINGE}

W RITING in NATURE in July 1918, I stated: "It behoves us to awaken and to take heed where we stand, or for some years to come our land will groan with the ery of desolation, due to our apathy and the ignorance and neglect of the ways and habits of our insectivorous birds, and the wanton destruction of what has ever been Nature's means of adjusting the complications of animal life, which man in his ignorance is seeking to pervert". In the quarter of a century which has since passed, the nation has lost millions of pounds worth of homegrown food.

For very many years past, I have given warning of the vital importance of framing $a$ sound and logical policy relating to the protection and destruction of wild birds. To a very large extent this warning has fallen on deaf ears. Little or nothing has been done, the laisser-faire policy has been pursued, and at the present moment it looks as if Nemesis were about to overtake us. No useful purpose would be served by re-opening here the whole question. It is a difficult one, touching various interests and prejudices; but we must no longer shut our eyes to the various extremely dangerous suggestions that are being so widely circulated, and, I fear, in some cases being put into practice.

At the moment, the whole of Great Britain is deeply concerned in the production of the maximum amount of home-grown food and in being able to harvest it. In so far as it lies in the range of human endeavour, there must be no mistakes made that will lessen the harvest of 1943. We now know that big, clean crops of all kinds can be raised and harvested, provided they are kept free from pests and disease. Such pests as wireworms, leatherjackets and other soil-inhabiting insect larvæ exact an enormous toll on root and cereal crops. In a like manner, the larvæ of various moths and flies, and also aphids, take their toll of the fruit and other crops. The soil may be treated with various chemicals and the fruit trees sprayed, but both are only partial remedies and both processes are expensive and demand man-power.

Two primary facts stand out, namely : (1) Wherever the insectivorous birds of a district or districts are destroyed, either purposely or through climatic or other causes, there is an accompanying insect oscillation which is not reduced until the balance of bird life is restored. (2) In the case of certain insects the numbers of which remain relatively constant, the controlling influence is largely, if not entirely, due to the uniformity of the bird life from year to year.

Nearly sixty years ago, John Curtis told us that if the depredations of injurious insects could be brought under control "the benefit would exceed everything of which at present we have any con. ception". The amount of insect food that insectivorous birds will eat is very large. I have given the following as an illustration and in an endeavour to bring the fact home to the public. Assuming that there are $32,000,000$ acres of land under cultivation in Great Britain and that we have a pair of birds to every four acres, these $16,000,000$ would consume annually $135,411,328,000$ insects, and these would be destroyed just at the season of the greatest agricultural activity and would be accomplished without any outlay of men or money. Yet it now seems that ill-informed people are advocating the destruction of rooks, gulls, blackbirds, thrushes and other insecteating birds.

Very briefly, let us examine the facts concerning the few species of useful birds mentioned above.

Rook. During the past fifty years, this species has received more attention as regards its food habits than any other British species, and the general consensus of opinion is that this bird is economically of the very greatest value. The nature of its food has been shown to consist of large quantities of injurious insects and their larvæ, some of which, are most difficult to destroy and which annually exact a huge toll on the produce of the land.

Sea-gulls. No more short-sighted policy than that of the destruction of sea-gulls has ever been promulgated, and if carried out will have results of a most devastating nature. We have at last given up the foolish idea that sea-birds generally feed only on fishes and therefore are impoverishing the supply. Nay, we have still further advanced, for we now realize that, so far as sea-gulls are concerned, the percentage of fish eaten is comparatively small, very small in some cases, and much of it is obtained from the garbage of the shore.

The black-headed gull-the bird that follows the plough-for the greater part of the year feeds upon injurious insects. The total percentage (stomach contents) for the year is $24 \cdot 70$, whereas the fish content is 3.73 per cent. The highest fish content for any month in the year was in November, with $12 \cdot 85$ per cent, whereas the percentage of injurious insects during April to October was 33.01, with the following figures respectively $32.96 ; 28.0 ; 37.30 ; 31 \cdot 38$; $38.83 ; 26 \cdot 62$; and $26 \cdot 0$.

"Of 664 specimens examined only 143 contained fish remains and 267 contained no marine organisms whatever."' For the common gull the figures were, injurious insects $14 \cdot 66$ per cent, fishes $5 \cdot 16$ per cent, and for the herring gull $9 \cdot 52$ per cent and $17 \cdot 55$ per cent respectively.

Blackbird. In 1924, I pointed out 2 that we had too large a resident population of blackbirds. From numerous observations made by myself and many correspondents, there was no doubt that the popula- 
tion seriously decreased during the winters of 1938-39 and 1939-40 (December to March) and investigations made during 1938 and 1939, when compared with similar ones made in $1933-34^{3}$, showed that there was an increase in the percentage of injurious insects eaten from 22.0 to 30.5 per cent, and a slight increase in the percentage of slugs and snails. There was a striking decrease in the percentage of cultivated fruits and fruit pulp, which dropped from $25 \cdot 5$ per cent to $15 \cdot 2$ per cent. Complaints respecting this bird have been very few during the past few years.

Thrushes. The missel-thrush and the song-thrush are the only ones that concern us. Of the total food consumed in a year by the former, 30.5 per cent consists of injurious insects and $16 \cdot 5$ per cent of cultivated fruits. The figures for the song-thrush are $32 \cdot 0$ per cent and $15 \cdot 0$ per cent respectively.

Tits. Who it was who first accused the tits of being injurious I do not know, but I fully agree with Yarrell that "none can be more mistaken than these men". The great tit consumes 66.5 per cent of injurious insects per year and $3 \cdot 6$ per cent of fruit, while the blue tit takes 78.0 per cent of injurious insects and $6 \cdot 0$ per cent of fruit.

The above figures need no comment; their significance is patent to every thinking man and woman.

There are certainly a few injurious birds, chief among which are the starling, the house-sparrow and the wood-pigeon. Repressive measures for dealing with these are long overdue.

In $1921 \mathrm{I}$ summed up my investigation ${ }^{4}$ on the starling by stating that, failing some action as there outlined, "the agriculturist and fruit-grower will be left faced with a growing enemy which is devastating their crops and inimical to their interests, and the country with a portentous factor which is adding to the scarcity of home-grown food. In short, the starling has become a plague in the land and a source of great national loss". Observations made during the past eleven years fully bear out this statement.

It has been estimated that the house-sparrow occasions a monetary loss of $£ 50,000,000$ a year. Whether this amount is correct or not is of little matter. What we do know is that they consume a large amount of home-grown food, and if they were reduced to half of their present number, it follows that half of the huge total would be saved.

Before it is too late, it is necessary that the beneficial species I have mentioned above should be scheduled and the destruction of them or their eggs be prohibited. I feel certain if this were done now, even if only as a temporary measure, it would demonstrate once and for all what a powerful factor they are in ensuring prosperous agriculture.

Writing some little time ago I stated", "The 'man in the street' and others in high places may not have realized this, but nevertheless it is true, and unless we do realise the facts and take action our agriculture, forestry and all kindred arts are doomed. These are strong words, but only uttered after a life-time's acquaintance with the subject. . . . The Government and the whole of agricultural Great Britain are evading a great and vital problem of paramount importance to the nation and charged with its future existence."

Long ago the prophet Joel wrote, "Tell ye your children of it, and let your children tell their children. . . That which the palmerworm hath left hath the locust eaten; and that which the locust hath left hath the cankerworm eaten ; and that which the cankerworm hath left hath the caterpillar eaten. . . The field is wasted, the land mourneth; for the corn is wasted. Be ashamed, $\mathrm{O}$ ye husbandmen, howl $\mathrm{O}$ ye vine-dressers for the wheat and for the barley; for the harvest of the field is perished."

Let us hope that we shall not have to give voice to similar words at the end of 1943 .

1 "The Food of Some British Wild Birds" (1924-27), p. 254

'J. Min. Agric., 31, 182-186 (1924).

' Ibis, 610-613 (1941).

4 J. Min. Agric., 27, 1114-1121 (1921).

${ }^{5}$ Nth. West. Nat., 15, 216-218 (1940).

\section{THE ACADEMY OF SCIENCES OF THE U.S.S.R.}

\section{PROGRAMME FOR 1943}

\section{BY ALEXANDER BAIKOV \\ Vice-President of the Academy}

$\mathrm{M}$ ORE than in any previous year, the plan of work for 1943 of the Academy of Sciences of the U.S.S.R. is designed to aid the Russian armed forces and war industries in securing a victorious termination of the War. Our main work will be directly concerned with improving armaments and therefore cannot be divulged; but it may safely be said that, if in the past year Soviet physicists, chemists and engineers did much to improve and increase the supply of materials, instruments and tools for war industries, in the New Year they will do considerably more.

Although the scientific effort of the country is almost entirely devoted to war needs, this does not mean that pure scientific research has been suspended. Russian mathematicians and physicists, for example, are continuing their investigations into the theory of numbers, the dynamics of the atmosphere, etc. However, the main effort this year will be focused on mobilizing the material resources of the country and increasing the supply of raw material for war industries. This work is under the direction of the Commission for the Mobilization of the Resources of the Urals, west Siberia and Kazakhstan, under the chairmanship of Vladimir Komarov (of the Academy), the Commission for Mobilization of the Resources of the Middle Volga and Kama Regions, and similar commissions which will make an all-round study of the problems involved. The plan of work of the Academy's geological and geographical department is devoted to exploration and study of new natural resources which may contribute to the country's defensive might, chiefly to the discovery of new deposits of manganese needed for manufacturing various alloys, aluminium, nickel, wolfram and other ores, as well as non-metallic minerals such as fireproof materials, for which there are now great industrial demands. Much work is also planned in locating new oil deposits and increasing the recovery in functioning oilfields. Great hopes are placed in the .Volga-Bashkir expedition. Oil will also be searched for in the Peprmian Kama coal deposits of the Tatar Republic. As before, considerable attention will be paid to the secondary recovery of oil. Adequate coal supply is just now decisive for industry in the U.S.S.R., and Soviet men of science will make every 